\title{
No Strategy Lasts Forever: Time for a New European Security Strategy
}

\author{
Sven Biscop*
}

\begin{abstract}
The European Security Strategy (ESS) needs revising. After a while, any strategic concept reaches the 'best consumed before' date and no longer serves to inspire and, most importantly, to drive policy and action. The ESS is incomplete as well, so more than reviewing, it needs completing. It operates at the grand strategic level, connecting large means and large ends. On the ends it remains vague, however. The ESS mostly gives us a method: the EU deals with foreign policy in a preventive, holistic and multilateral way. As a debate about a new ESS is beginning in the 'Brussels hub', this paper will assess what a review would imply in terms of substance, and through which method it could be achieved.
\end{abstract}

Keywords: European Security Strategy, Common Foreign and Security Policy, Common Security and Defence Policy, European External Action Service

Europäische Sicherheitsstrategie, Gemeinsame Außen- und Sicherheitspolitik, Gemeinsame Sicherheits- und Verteidigungspolitik, Europäischer Auswärtiger Dienst

\section{Introduction}

$\mathrm{N}$ o strategy lasts forever. The time has come to review and complete the 2003 European Security Strategy (ESS). The necessity is evident; and so is the opportunity, with the entry into force of the Lisbon Treaty. The new External Action Service needs a clear mandate: a new strategy. The debate has slowly started, following a formal proposal by Sweden in mid-2011 to review the ESS by 2013, ten years after its adoption. At the March 2012 Gymnich meeting, Finland, Poland and Italy spoke out in favour of a review, but as the majority of member states, including the 'big three', remain reluctant, as does High Representative (HR) Catherine Ashton, no decision has yet been taken on the future of the ESS. Meanwhile, the debate continues in the 'Brussels hub' and the pan-European think-tank scene. ${ }^{1}$ This paper sets out to assess what a review would entail in terms of substance, and by what method it could be achieved.

\section{The Core of the ESS}

The ESS is a rare thing: a security strategy of a sui generis statelike international actor, covering both intergovernmental and supranational policy areas. ${ }^{2}$ For in spite of its title, the ESS covers all European Union (EU) external action, from aid and trade to diplomacy and defence. It thus operates at the level of grand strategy, 'connecting large means and large ends'. ${ }^{3}$ The core of the ESS can be summarised in three principles, which together constitute an approach, a method, to deal with the international environment.

* Professor Dr Sven Biscop is director of the Europe in the World Programme at Egmont - Royal Institute for International Relations in Brussels, and teaches at Ghent University and the College of Europe in Bruges.

1 For a good overview see J. J. Andersson, E. Brattberg, M. Häggqvist, H. Ojanen and M. Rhinard, 'European Security Strategy: Reinvigorate, Revise or Reinvent?', UI Occasional Paper 7, 2011, Swedish Institute of International Affairs, Stockholm, available at www.ui.se/Files.aspx?f_id=56515.

2 For a comprehensive analysis see S. Biscop and J. Coelmont, Europe, Strategy and Armed Forces. The Making of a Distinctive Power (Abingdon: Routledge, 2011).

3 J. L. Gaddis, 'What is Grand Strategy?', Karl Von Der Heyden Distinguished Lecture, Duke University, 26 February 2009, available at www.duke.edu/web/ agsp/grandstrategypaper.pdf.
The first core principle is prevention: 'we should be ready to act before a crisis occurs. Conflict prevention and threat prevention cannot start too early', as the ESS states. A permanent strategy of prevention and stabilisation, addressing the root causes of threats and challenges, aims to prevent conflict so that, ideally, coercion and the use of force will not be necessary. Addressing the root causes means closing the gap, both within and among countries, between the haves and the have-nots in terms of access to the core public goods to which all individuals aspire, and to which all are indeed entitled: security, prosperity, freedom and social well-being. For this gap generates feelings of frustration and marginalisation on the part of those who are excluded economically or politically, as well as radicalisation and extremism of various kinds, social and economic instability, massive migration flows and tension and conflicts within and between states. The gap in access to core public goods thus constitutes a fundamental root cause of instability. Effective prevention is an enormous challenge, as it means addressing a much wider range of issues at a much earlier stage across the globe, because as the ESS says, 'the first line of defence will often be abroad'.

Closing the gap between the haves and the have-nots of necessity demands a holistic approach, the second principle. The security, economic, political and social dimensions are inextricably related - an individual cannot enjoy any one core public good unless having access to them all - and all are present, in differing degrees, in all threats and challenges. In the ESS, "none of the new threats is purely military, nor can any be tackled by purely military means. Each requires a mixture of instruments.' Therefore every foreign policy must simultaneously address all dimensions, making use in an integrated way of all available instruments: 'Diplomatic efforts, development, trade and environmental policies, should follow the same agenda.' The core phrase in the ESS is perhaps the following:

The best protection for our security is a world of well-governed democratic states. Spreading good governance, supporting social and political reform, dealing with corruption and abuse of power, establishing the rule of law and protecting human 
rights are the best means of strengthening the international order.

Such a holistic approach is best implemented via multilateralism, the third principle. 'We need to pursue our objectives both through multilateral cooperation in international organizations and through partnerships with key actors', according to the ESS. Only in cooperation with others can our objectives be achieved peacefully, only in cooperation with all global actors can global challenges be successfully addressed and only in cooperation with a wide range of actors can complex issues be comprehensively tackled. 'The development of a stronger international society, well functioning international institutions and a rule-based international order is our objective', declares the ESS under the heading of 'effective multilateralism'. Multilateralism can here be considered 'effective' to the extent that the ensemble of regimes, mechanisms and institutions manages to provide access to the core public goods to citizens worldwide.

From these three principles it follows that the EU must be a global actor. As the ESS states: 'As a Union of 25 [now 27] states with over 450 million people producing a quarter of the world's Gross National Product (GNP), and with a wide range of instruments at its disposal, the European Union is inevitably a global player.' In a globalised world, interdependence is such that none of these principles can be successfully applied at the regional level alone, for the most pressing challenges are global. The EU cannot insulate itself or its neighbourhood from the world.

These are indeed principles of foreign policy, which reflect the values on which the EU itself is based. From these principles, the ESS draws some implications for the means, notably the need to be more active, more capable and more coherent, and to work with partners.

\section{Necessity of and Opportunity for a Review}

The ESS needs revising. Adopted by the European Council back in 2003, it has lost its flair. That is not a criticism of the ESS, the contents of which remain valid, but an unavoidable reality. After a while, any strategic concept reaches the 'best before' date and no longer serves to inspire and, most importantly, to drive policy and action. The Report on the Implementation of the European Security Strategy, adopted by the European Council in December 2008, did not rectify this, being insufficiently concrete and prospective. In comparison, the 2002 US National Security Strategy that immediately preceded the ESS has since been reviewed not once but twice. And that is not to mention the updates of its various sub-strategies, such as the strategic guidance document Sustaining US Global Leadership: Priorities for 21st Century Defense, issued by the U.S. Department of Defense in January 2012.

The latter announces, or confirms, the shift of focus of American strategy from Europe and its neighbourhood to the Asia-Pacific. The potential impact on EU foreign and security policy is enormous. The same goes for the Arab Spring and its consequences, and for the massively increased role of the emerging powers on the global scene since 2003. None of these events and developments can be dealt with at the level of substrategies, for they may necessitate a reorientation of priorities by the EU, and consequently a transfer of means and effort from one sub-strategy to another. A grand strategic perspective at foreign and security policy overall is thus a necessity, not a luxury. This is not about theorising EU policy, but about driving EU action. Of course foreign and security policy is, to a large extent, about 'events' and reacting to them. But that in no way precludes the pursuit of a proactive agenda seeking to anticipate and to shape the world. The European External Action Service (EEAS) received its baptism of fire reacting to the events of the Arab Spring. Now the time has come to set priorities for a proactive foreign policy.

The ESS is incomplete - more than reviewing, it needs completing. The ESS mostly gives us a method: the EU deals with foreign policy in a preventive, holistic and multilateral way. In other words, the ESS tells us how to do things, but not really what to do. The choice of this particular method is a crucial strategic decision, but because the EU and member states have not translated it into clear priorities, it has not generated sufficient action. Nor has it had a real impact on the development of means and capabilities, on which the ESS also remains vague.

That is not to say that the EU is inactive - far from it. But without clear strategic objectives connecting its actions, it underperforms. Its actions have less effect than they could, for strategy functions as a multiplier. Without a more complete strategy, two of the key aims of the ESS - preventive action and rapid reaction - are virtually impossible; witness is the initial improvisation on Libya. By contrast, other global powers often have a much clearer idea of their interests and objectives and thus act in a much more purposive and resolute manner. In interaction with these powers, the EU is bound to fall short if it retains its current, mostly reactive outlook.

Fortunately, there now is an ideal opportunity to revisit the ESS. The entry into force of the Lisbon Treaty has generated great expectations both within and outside the EU. What will the EU do with its enhanced foreign policy machinery? A new ESS adopted by the heads of state and government in the European Council would provide the answer. The priorities it sets should then steer the next EU budgetary cycle. In times of financial constraint, prioritisation is more necessary than ever. At the same time, such a strategic review would serve to foster an esprit de corps within the EEAS, align the external actions of the EEAS and the European Commission, and forge a common view in the capitals of member states. Engaging in a comprehensive and thorough strategic reflection involving all components of the EEAS would be an excellent way of forging the beginnings of a shared culture and outlook in the new service. The review process in itself is essential, as Robert Hunter notes: 'following the conclusion of the exercise, everyone has a better idea of where each ally stands, what the agenda ... is likely to be, and, in general, a set of overall aspirations'. ${ }^{4}$

4 R. Hunter, 'NATO's Strategic Focus: Satisfying All of the Allies', American Foreign Policy Interests, 31 (2009): 78-89. 


\section{Desired Outcome}

The process is important, but what really counts of course is the result: a new ESS. That should definitely confirm the preventive, holistic and multilateral outlook of the EU, but ought to complement it with much clearer objectives and thus priorities. Furthermore, it should provide more guidance about the required means and capabilities, civilian, military and institutional. The European Council is the only body carrying sufficient weight to provide a real impetus for collective capability development.

The end result will be an ESS constituting a strong, clear and broad mandate for EU external action across the board, in the areas of competence of the Council/EEAS as well as the European Commission. That will strengthen the opportunity and legitimacy for the key EU-level actors to take the initiative: President of the European Council Herman Van Rompuy, HR Catherine Ashton and the relevant commissioners. Only when they, at their own level, act early to initiate policy and stimulate the member states is effective preventive action possible.

The outcome need not be limited to a new ESS, though. The European Council can further give a tasking to develop specific sub-strategies and take action in policy areas that are prioritised in the new ESS. One very useful tasking would undoubtedly concern means and capabilities, notably the implementation of the 'Ghent Process' for military capability development, seeking to stimulate member states to retain relevant capabilities and create new ones meeting the strategic shortfalls by way of pooling and sharing their efforts.

\section{Drafting the Method}

The open debate about the original ESS, through seminars involving a wide array of stakeholders, was an important innovation that should be preserved, in order to create the widest possible sense of ownership of its successor, while avoiding the mistakes of the 2008 review. A real strategic review requires incisive debate that does not shy away from difficult questions and constructive criticism.

In 2003 the first draft of the ESS was written by a small team around then HR Javier Solana. After the June European Council had endorsed it as a basis for further work, three seminars were organised, through the EU Institute for Security Studies, to discuss the three chapters of the draft. Bringing together officials from the EU and member states, and also from important partner countries, plus academics, NGOs and the media, these seminars made for a very inclusive and thorough debate. At the same time, line-by-line discussion of the draft in the formal EU bodies was avoided, ensuring that the final text of the ESS adopted by the December European Council was short and sharp.

The same method of inclusive seminars was adopted in 2008, when a first attempt was made to revisit the ESS. This effort was inconclusive. To start with, the mandate of the exercise set by the December 2007 European Council remained ambiguous: 'to examine the implementation of the Strategy with a view to proposing elements on how to improve the implementation and, as appropriate, elements to complement it'. Secondly, the timing was difficult, before the entry into force of the Lisbon Treaty. When, just after the first seminar, Ireland rejected the treaty in a referendum, all political energy for the review dissipated. Finally, without draft texts to discuss, the debates remained rather stale.

If a real, substantial review is to be undertaken, first of all the mandate should be clear, and then the method of 2003 should be used.

- Seminars involving all stakeholders in ESS implementation (the president of the European Council, member states, the HR, the EEAS, the European Commission, the European Parliament), as well as all external actors that can make a substantial contribution (academia, NGOs, the media, the most significant partner countries and organisations).

- Setting specific questions for debate in parallel working groups rather than vague plenary discussions.

- Producing incisive discussion notes to launch the debate, by the president of the European Council, the HR and the European Commission.

- Inviting external speakers to offer constructive criticism and specific recommendations.

- Doing the final drafting in a small team, led by the HR, and integrating the advisers of the president of the European Council and the relevant commissioners.

- Most importantly, starting from a blank sheet of paper so as to invite creative thinking, even if the basic philosophy of the current ESS is to be preserved.

In 2013 at the latest, ten years after the original, this process should produce a new ESS.

\section{Substance of the Review: Values and Interests}

The ESS starts from the philosophy that durable stability can only be achieved where security, prosperity, democracy and equality are guaranteed to all citizens. Promoting those four core values in the rest of the world is thus the best way to safeguard them for ourselves. To that end, the EU pursues a holistic, preventive and multilateral foreign policy: putting to use in an integrated way the full range of instruments of external action to address the root causes of instability and conflict, in partnership with others. That method is still valid and should be preserved.

To translate this method into clearer objectives and priorities, the review process should start from the EU's vital interests: defence against any military threat to EU territory; open lines of communication and trade; a secure supply of energy and other vital natural resources; a sustainable environment; manageable migration flows; the maintenance of international law and universally agreed rights; and preserving the autonomy of the decision-making of the EU and its member states.

Taking into account values and interests, and preserving the method, priorities can then be outlined in key areas. 
- Revitalising the European Neighbourhood Policy, fostering democratisation and rendering conditionality more consistent, effective and credible. ${ }^{5}$

- Developing a horizontal view on the strategic partnerships, instrumentalising them in functioning of horizontal foreign policy priorities and developing a view on the reform of the multilateral architecture. ${ }^{6}$

- Defining priority regions and issues for the Common Security and Defence Policy (CSDP), as a tool to guide decisionmaking on operations and capability development. ${ }^{7}$

Indeed, more specific implications for the necessary means and capabilities can be defined, notably in the areas of intelligence gathering and the planning and conduct of preventive action and rapid reaction.

Although not everybody recognises it, the current ESS and the report on its implementation have a much broader scope than the CSDP and even the Common Foreign and Security Policy they really concern the whole of EU external action. The scope of the new ESS should be unambiguous: it is the guiding framework for all areas of external competence of the EEAS and the European Commission, with the HR at the head, who will coordinate with the relevant commission competences under the overall guidance of the European Council and its president. This broad scope can be reflected in a change of title: from ESS to European Global Strategy.

\section{Follow-Up of the Review}

One reason why the current ESS has lost its inspirational function is the lack of follow-up: no reporting or review mechanism was created, hence there was no bureaucratic necessity to continue to refer to it in the decision-making process, in spite of its continued presence in EU discourse. And as the specific objectives and means were left undefined and no action plan to generate them was adopted, no benchmarks to assess implementation existed. It was also forgotten that once adopted and disseminated, the ESS acquires a life of its own: whether the EU likes it or not, others (the public, but also third states) will see it as the benchmark against which to judge EU action. Therefore, clear reporting and reviewing mechanisms are required so as not to lose the link between the grand strategic framework and day-to-day decision-making.

Annual reporting and debate on the effectiveness of EU external action, i.e. policy evaluation, should take place through the lens of the ESS that guides it, in the European Council as well as in the European Parliament. Policy evaluation at this strategic level will inter alia allow one to identify in which areas there is a lack of translation into sub-strategies and implementation, and in which areas EU policies are overlapping or contradicting each other. Identifying the de facto sub-strategies is an important part

5 S. Biscop, R. Balfour and M. Emerson (eds), 'An Arab Springboard for EU Foreign Policy?', Egmont Paper 54, 2012, available at www.egmontinstitute. be/paperegm/ep54.pdf.

6 T. Renard, 'The Treachery of Strategies - A Call for True EU Strategic Partnerships', Egmont Paper 45, 2011, available at www.egmontinstitute.be/ paperegm/sum/ep45.html.

7 S. Biscop and J. Coelmont (eds), 'Europe Deploys - Towards a Civil-Military Strategy for CSDP', Egmont Paper 49, 2011, available at www.egmontinstitute. be/paperegm/sum/ep49.html. of the reporting mechanism. Such annual policy evaluation could be combined with a forward-looking 'European security estimate', assessing the international environment. Together, they can inform an annual 'State of the EU Global Strategy', in which the HR outlines priorities for the coming year. Finally, reviewing the ESS itself should not be accidental but systematic, e.g. at least every five years or at least with every start of a new or renewed mandate of the HR.

\section{Conclusion}

The EU has at its disposal many of the instruments, tools and means that it needs. But means only acquire meaning if they serve an end. That, unfortunately, is less clear today. As Joseph Nye emphasises:

Power-conversion strategies turn out to be a critical variable that does not receive enough attention. Strategies relate means to ends, and those that combine hard and soft power resources successfully in different contexts are the key to smart power. ${ }^{8}$

If asked what EU foreign policy is about these days, no answer readily comes to mind. The EU lacks clear foreign policy priorities. Europe does invest a huge diplomatic, economic, military and civilian effort in many important issues. But in spite of that, few see the EU as the game-changer on the key issues of the day. Its efforts are not focused enough and it lacks a clear strategic narrative. The EU and member states thus need to decide where they want to make their mark collectively. Only that can generate the necessary drive and sense of purpose to give meaning to the External Action Service.

The aim of a strategic review should not be to try to find consensus on each and every item of foreign policy - that would be impossible in a union of 27 member states. The aim should rather be to identify those priorities on which member states agree there is added value in collective action, not to supplement but to complement their national foreign policies. The EEAS ought not to be the 28th foreign ministry, but to play a distinctive role, inspired by the vital interests of the EU as a whole and focusing on those issue areas where it can bring the greatest added value by aggregating both the power of 27 member states and the instruments of all dimensions of EU external action. That does require that the member states mandate the EU institutions to initiate policy on their behalf once these priorities have been defined in a new ESS.

A security strategy is often the codification ex post of an orientation that has already developed in practice. It was no different when the ESS was adopted in 2003. Writing or reviewing a security strategy is thus not an objective in its own right, but an instrument to improve the quality of policy and decision-making. What is crucial today is that EU member states collectively debate the important events and developments (the American strategic shift, the Arab Spring, multipolarity...) that have an impact on all their foreign policies. Deciding on a review of the ESS would be one way of generating momentum for this key strategic debate.

8 J. S. Nye, The Future of Power (New York: Public Affairs, 2011), p. 10. 